\title{
The site-specific recombination locus of mycobacteriophage Ms6 determines DNA integration at the tRNAAla gene of Mycobacterium spp.
}

\author{
Acilino Freitas-Vieira, Elsa Anes and J. Moniz-Pereira \\ Author for correspondence: J. Moniz-Pereira. Tel: +3511 7946430. Fax: +35117934212 \\ e-mail: jpereira@ff.ul.pt
}

Laboratório de

Microbiologia Molecular, Faculdade de Farmácia, Universidade de Lisboa, Av. das Forças Armadas, 1600 Lisboa, Portugal

\begin{abstract}
Genetic determinants of the temperate mycobacteriophage Ms6 required for chromosomal integration were identified. DNA sequence analysis of an attPcontaining fragment revealed an ORF encoding a protein of 372 amino acid residues with a C-terminus similar to other conserved C-terminal regions typical of the phage integrase family. Comparison of the sequences of attP, attB and bacteria-prophage junctions attL and attR showed a 26 bp common core sequence, where recombination takes place, near the 5' end of the integrase gene. Nucleotide sequence analysis of the attB chromosomal region showed that the core site overlaps the $3^{\prime}$ end of the tRNA ${ }^{A l a}$ gene. An integration-proficient plasmid vector was constructed and efficiently inserted at the tRNAAla gene of Mycobacterium smegmatis, Mycobacterium vaccae, Mycobacterium bovis BCG and Mycobacterium tuberculosis H37Ra. It was demonstrated that Ms6 and D29 integrative systems can be used in conjunction for inserting genes at multiple loci. The site-specific integration system of mycobacteriophage Ms6 is a new tool for mycobacterial genetic analysis and is poorly related to those of the L5 bacteriophage family.
\end{abstract}

Keywords: Mycobacterium phage, site-specific recombination, tRNA ${ }^{\text {Ala }}$, integrative vectors

\section{INTRODUCTION}

Many temperate bacteriophages integrate their DNA into the host chromosome by a site-specific recombination mechanism following the Campbell model (Campbell, 1962). The recombination event is catalysed by a phage-encoded recombinase and involves a common core sequence present in both phage $(a t t P)$ and bacterial (attB) genomes. The integrase family of recombinases was identified in temperate coliphages and contains proteins that share four absolutely conserved residues: two arginines, one histidine and one tyrosine (Abremski \& Hoess, 1992; Argos et al., 1986). Recombinases belonging to the integrase family were found in temperate bacteriophages of both Gramnegative (Argos et al., 1986; Leong et al., 1986) and Gram-positive (Lee \& Iandolo, 1986, 1988; Lee et al.,

The GenBank accession number for the sequence reported in this paper is AF030986.
1991 ; Lillehaug \& Birkeland, 1993 ; Rausch \& Lehmann, 1991) bacteria. In actinomycetes, integration of plasmids, such as pSAM2 (Boccard et al., 1989), pSE211 (Brown et al., 1990), pSE101 (Brown et al., 1994) and SLP1 (Brasch et al., 1993), is also mediated by sitespecific recombinases. Recently, a different type of phage-encoded enzymes, resolvase-like proteins, were shown to mediate site-specific integration in Lactococcus lactis (Christiansen et al., 1996) and Streptomyces strains (Matsuura et al., 1996).

Integration into the bacterial genome by site-specific recombination can occur in genes (Christiansen et al., 1994; Lee \& Iandolo, 1986; Rausch \& Lehmann, 1991), in intergenic regions (Lee \& Iandolo, 1988; Rausch \& Lehmann, 1991) or in tRNA genes (Campbell, 1992; Reiter et al., 1989). Therefore, the identification of the attachment site in the host genome of a new integrative genetic element provides a genetic marker for chromosomal mapping (Canard \& Cole, 1990) and may help in the identification of new genes. 
Table 1. Bacterial, Strains, plasmids, phages and primers used in this study

Strain, plasmid,phages

Description

Reference or source

or primer

Bacterial strains

Escherichia coli

XL1-Blue MRA

XL1-Blue MRA(P2)

Top10 $\mathrm{F}^{\prime}$

JM109

Mycobacterium spp.

M. smegmatis $\mathrm{mc}^{2} 155$

M. bovis BCG

M. tuberculosis H37Ra

Plasmids

pCR3

pAV8800

pAV1

pRR3

pRM16

pAV $\Omega$

Phages

Ms6

$\lambda$ EMBL4

M13mp18/1)

Primers $\left(\mathbf{5}^{\prime}-\mathbf{3}_{\mathbf{j}}\right)$

C2

PRPAV10

P1

M1
Designed to prepare $\lambda$ EMBL4 vector

Designed to select $\lambda$ EMBL4 recombinant clones

Eukaryotic TA cloning kit

Host for M13mp vectors, $\operatorname{rec} A$

High-transformation-efficiency mutant

Vaccine strain $1173 \mathrm{P} 2$

Non-virulent strain

Vector for cloning PCR products

$4.8 \mathrm{~kb}$ BgllI Ms6 attP-int fragment in pUC19, $\mathrm{Km}^{\mathrm{r}}$

$1818 \mathrm{bp} \mathrm{Ms} 6$ integrative cassette in pCR3

E. coli-Mycobacterium shuttle vector

$1.6 \mathrm{~kb}$ PmaCI-SmaI D29 attP-int fragment

in $\mathrm{pBK}-\mathrm{CMV}$ (Stratagene), $\mathrm{Km}^{\mathrm{r}}$

273 bp attP-Ms6 in pUC18, $\operatorname{Strp}^{r}$ ( $\Omega$ gene)

Temperate phage from $M$. smegmatis

Genomic replacement vector

Single-stranded sequencing vector

GATCCGGGCCTCGTACTCG

CAACCCGACGGTGTTGCG

CGCTGTTGGTGGGCCTGATCG

ACACGCCGGATGAATGACC
Stratagene

Stratagene

Invitrogen

Yanisch-Perron et al. (1985)

Snapper et al. (1990)

Pasteur Institute collection

Pasteur Institute collection

Invitrogen

This study

This study

Ranes et al. (1990)

This study

This study

Portugal et al. (1989)

Stratagene

Pharmacia

This study

This study

This study

This study
In mycobacteria, the only well-documented site-specific integration system is that of temperate mycobacteriophage LS. Integration of L5 DNA occurs in the tRNA $^{\text {Gly }}$ gene of Mycobacterium smegmatis by recombination within a $43 \mathrm{bp}$ sequence present in both phage and mycobacterial genomes (Lee et al., 1991). The development of integrative vectors derived from the sitespecific recombination of bacteriophage L5 allowed complementation experiments for genetic analysis in mycobacteria to be performed (Dussurget et al., 1996; Pascopella et al., 1994) and the construction of stable recombinant Mycobacterium bovis BCG strains for multivalent vaccination (Stover et al., 1991).

To improve our understanding of lysogeny in mycobacteria, we studied the site-specific integration of Ms6 bacteriophage DNA into the mycobacterial chromosome. We have previously described some properties of mycobacteriophages Ms6, including the ability to form stable lysogens in strains of $M$. smegmatis (Portugal et al., 1989; Anes et al. 1992). In this paper we report the site-specific integration system of mycobacteriophage Ms6, and demonstrate that this system can direct the insertion of heterologous DNA into the tRNA ${ }^{\mathrm{Ala}}$ gene of M. smegmatis. An Ms6-derived integrative plasmid vector was constructed and inserted by electroporation into Mycobacterium vaccae, M. bovis BCG and Mycobacterium tuberculosis $\mathrm{H} 37 \mathrm{Ra}$ genomes. The transformants were stably maintained after several generations. Stable recombinant $M$. bovis BCG vaccines expressing multiple antigens can be produced using integrative expression vectors based on the integration functions of mycobacteriophage Ms6.

\section{METHODS}

Bacteriophages, bacterial strains and plasmids. The bacteriophages, bacterial strains and plasmids used in this study are listed in Table 1. Growth conditions were as previously described (Anes et al., 1992). $M$. bovis BCG and $M$. tuberculosis were grown in Middlebrook $7 \mathrm{H} 9$ medium, supplemented with an albumin, dextrose and catalase enrichment from Difco.

DNA manipulation and sequencing. DNA manipulations, phage and bacterial chromosomal DNA extractions, transformation, electrophoresis, restriction endonuclease digestion, Southern blotting and hybridizations were carried out using standard techniques (Sambrook et al., 1989).

The $4.8 \mathrm{~kb}$ BglII fragment from purified Ms6 phage particles was sheared by sonication (Deininger, 1983) and inserted into 
M13 sequencing vectors (Yanisch-Perron et al., 1985). Singlestranded DNA was prepared from randomly chosen clones and sequenced using the Deaza G/A ${ }^{\text {T7}}$ Sequencing Mixes (Pharmacia). Sequences from over 150 clones were determined and aligned with the ASSEMGEL program of PCGene (IntelliGenetics) to form a contiguous sequence. Towards the end of the project, oligonucleotide primers were used to complete the DNA sequence on both strands, and a small number of clones were constructed using restriction enzyme cleavage of the $4.8 \mathrm{~kb} \mathrm{BglII}$ fragment of the Ms6 DNA. ORFs and other features were identified using the PCGene (IntelliGenetics) programs.

Isolation of attR, attL and attB DNA. The chromosomal DNA of an M. smegmatis strain containing the integrative plasmid pAV8800 (see Table 1) was digested with EcoRI, extracted with phenol/chloroform and precipitated with ethanol. EcoRI restriction fragments $(10 \mu \mathrm{g})$ were ligated to $1 \mu \mathrm{g} \lambda \mathrm{EMBL} 4$ arms previously digested with EcoRI and treated with calf intestine alkaline phosphatase (Stratagene) in a $2 \mu \mathrm{l}$ final volume. Then, $1 \mu \mathrm{l}$ of the ligation mix was packaged in vitro using Gigapack II XL packaging extract (Stratagene), as recommended by the suppliers. Recombinant phages containing the DNA junctions attR and attL between pAV8800 and the chromosome were isolated by screening the $\lambda$ library with the radiolabelled attP sequence. Two hybrid Sall fragments $(0.9$ and $1.2 \mathrm{~kb})$ were subcloned into the M13mp18 and M13mp19 vectors and sequenced (Sanger et al., 1977). The oligonucleotides P1 and M1 (Table 1) were designed from the nucleotide sequences of $a t t L$ and $a t t R$ DNAs and used to amplify a 496 bp fragment (attB) from the chromosomal DNA of a non-lysogenic $M$. smegmatis strain.

PCR amplification was carried out with $100 \mathrm{ng}$ chromosomal DNA, $10 \mathrm{pmol}$ primers (shown in Table 1), $250 \mu \mathrm{M}$ dNTPs, $2 \mathrm{mM} \mathrm{MgSO}_{4}$ and $2 \mathrm{U}$ Taq DNA polymerase (Gibco) in a final volume of $50 \mu \mathrm{l}$. Reactions were carried out for 30 cycles as follows: denaturation at $95^{\circ} \mathrm{C}$ for $3 \mathrm{~min}$ (except in the first cycle: $5 \mathrm{~min}$ at $95^{\circ} \mathrm{C}$ ), primer annealing at $65^{\circ} \mathrm{C}$ for $2.25 \mathrm{~min}$ and primer extension at $70^{\circ} \mathrm{C}$ for $1 \mathrm{~min}$.

Construction of the integrative plasmid pAV1. The integrative cassette of Ms6 was amplified by PCR of $10 \mathrm{ng}$ phage DNA, using primers C2 and PRPAV10 (Table 1). PCR amplification was carried out in $100 \mu \mathrm{l} 1 \times$ Gibco buffer containing $250 \mu \mathrm{M}$ dNTPs, $2 \mathrm{mM} \mathrm{MgSO}, 10 \mathrm{pmol}$ each primer and 2 U Taq DNA polymerase (Gibco). Thirty cycles were performed as follows on a Hybaid Omnigene thermal cycler: 1 min at $95^{\circ} \mathrm{C}$ for denaturation (except $5 \mathrm{~min}$ at $95^{\circ} \mathrm{C}$ for the first cycle), $30 \mathrm{~s}$ for primer annealing at $55^{\circ} \mathrm{C}$ and $1.5 \mathrm{~min}$ at $70^{\circ} \mathrm{C}$ for strand synthesis. A final cycle for $5 \mathrm{~min}$ at $72{ }^{\circ} \mathrm{C}$ was performed to incorporate $\mathrm{T}$ protruding ends. The 1818 bp PCR product was purified by phenol/chloroform extraction, precipitated with ethanol and ligated into the linearized vector pCR3 of the Eukaryotic TA cloning kit (Invitrogen).

\section{RESULTS}

\section{Localization of the Ms6 attP site}

To locate the phage attachment site $(a t t P)$ on the Ms6 genome, a comparison of Southern blots of lysogenic genomic DNAs and the DNA extracted from mycobacteriophage was carried out. This revealed a new $5.8 \mathrm{~kb} \mathrm{BglII}$ band in lysogens, representing the hybrid phage-host junction that was absent from the phage
Table 2. Transformation efficiency of Ms6 derived integrative vectors

\begin{tabular}{|lccr|}
\hline & \multicolumn{3}{c|}{ Transformants $(\mu \mathrm{g} \text { DNA })^{-1}$} \\
\cline { 2 - 4 } Strain & pAV8800 & pAV1 & pRR3 \\
\hline M. smegmatis & $1 \cdot 3 \times 10^{4}$ & $1.0 \times 10^{5}$ & $>10^{5}$ \\
M. vaccae & $1 \cdot 2 \times 10^{4}$ & $\mathrm{ND}$ & $8.0 \times 10^{4}$ \\
M. bovis BCG & 4.0 & $3.0 \times 10^{3}$ & $4.0 \times 10^{3}$ \\
M. tuberculosis H37Ra & $\mathrm{ND}$ & $3.0 \times 10^{3}$ & $4.0 \times 10^{3}$ \\
\hline
\end{tabular}

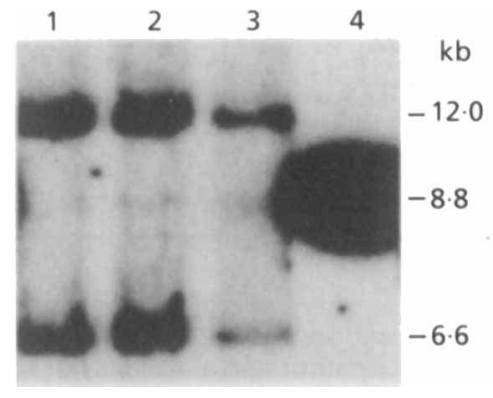

Fig. 1. Southern-blot analysis of pAV8800 transformants (lanes 1-3) with a putative restriction fragment harbouring the Ms6 attP region as probe $(4.8 \mathrm{~kb} \mathrm{Bg} / \mathrm{ll}$ or $0.8 \mathrm{~kb}$ Sall fragment). The junction fragments correspond to both 12 and $6.6 \mathrm{~kb}$ ECORI fragments in the electrophoretic profile of all transformants. The $8.8 \mathrm{~kb}$ EcoRI fragment in lane 4 is linear pAV8800 DNA.

DNA digest. This suggested that the attP site was located in the $4.8 \mathrm{~kb} B g / \mathrm{II}$ fragment (results not shown). Taking into consideration that, in the majority of the prokaryotic site-specific integration systems, the integrase (int) gene is close to the attP site, the $4.8 \mathrm{~kb} \mathrm{BglII}$ fragment was cloned into the pUC19-derived plasmid $\mathrm{pZM} 3$, and the resulting recombinant plasmid (pAV8800) was electroporated into $M$. smegmatis $\mathrm{mc}^{2} 155$. Kanamycin-resistant transformants were obtained with a transformation efficiency of $5 \cdot 3 \times 10^{4}$ per microgram of DNA (Table 2). Southern-hybridization analysis of transformant DNA probed with pAV8800 showed the same profile for all transformants, two hybrid bands (Fig. 1) that were not present in the pAV8800 digest, confirming the insertion of pAV8800 at a specific site of the bacterial genome. These data demonstrate that the $4.8 \mathrm{~kb} B g l \mathrm{II}$ fragment contains the complete site-specific integration locus of bacteriophage Ms6.

The localization of the attP site within the $4.8 \mathrm{~kb} \mathrm{Bg} / \mathrm{II}$ fragment was further checked by Southern-hybridization analysis using three different regions of this fragment as probes $(0.8 \mathrm{~kb}$ Sall, $0.4 \mathrm{~kb}$ Sall and $2.4 \mathrm{~kb}$ SspI-HindIII restriction fragments) (Fig. 2a). The hybridization patterns probed with the $0.8 \mathrm{~kb} S a l \mathrm{I}$, 
(a)

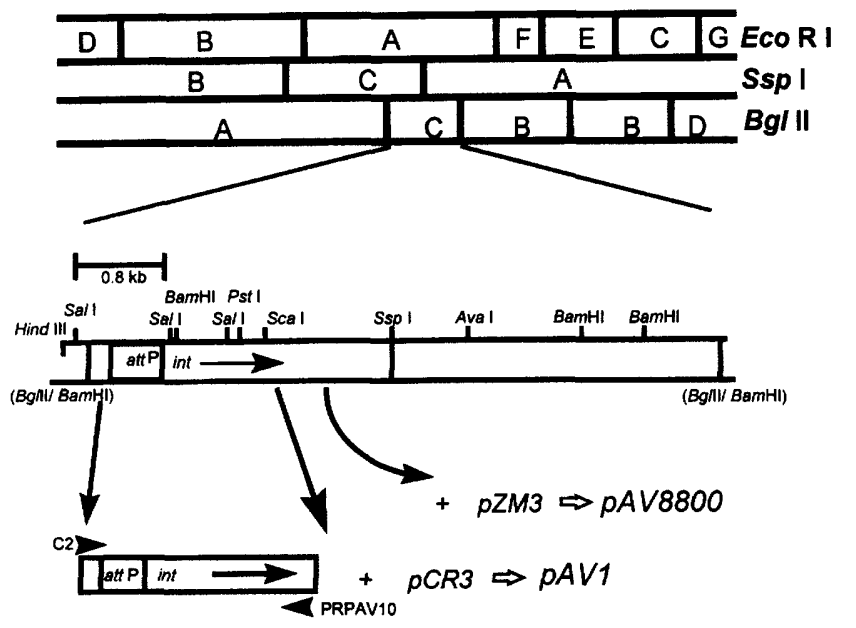

(b)

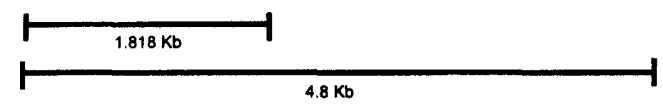

DOMAIN 1

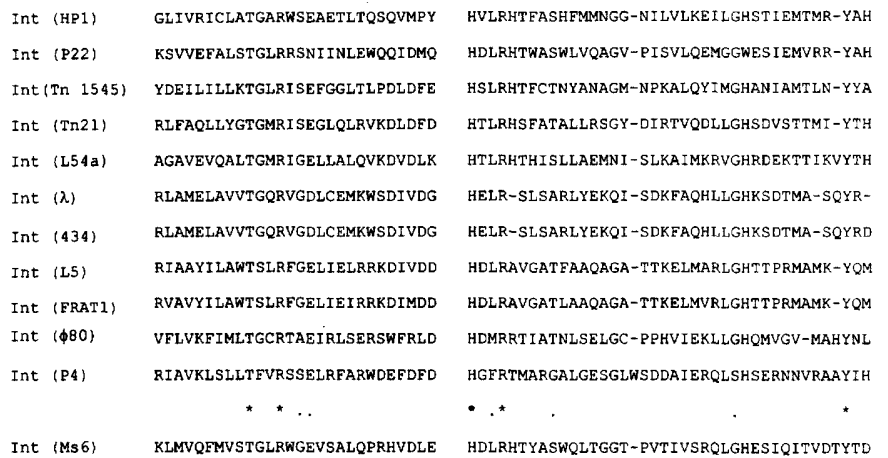

Fig. 2. Organization and nucleotide sequence of the Ms6 integrative region. (a) Restriction map of the $4.8 \mathrm{~kb} B g / l \mathrm{l}$ fragment. The location and translational direction of the int gene are represented as an arrow on the right of the attP site. C2 and PRPAV10 are primers designed for PCR amplification of the attP-int region. (b) Amino acid sequence comparison of the C-terminal regions of integrases of the Int family and Ms6 Int protein. Perfectly conserved amino acids are indicated by asterisks and highly conserved amino acids by dots.

$2.4 \mathrm{~kb}$ SspI-HindIII or $4.8 \mathrm{~kb}$ BglII fragments were the same (Fig. 1). This shows that the attP site is in the $0.8 \mathrm{~kb}$ Sall fragment at the left end of the $4.8 \mathrm{~kb}$ BglII fragment (Fig. 2a).

\section{Nucleotide sequence and genetic organization of the integration region}

To identify the Ms6 site-specific integration locus and knowing that the attP site was located in the $0.8 \mathrm{~kb}$ $B g l \mathrm{II}-S a l \mathrm{l}$ fragment, we sequenced the $2 \cdot 2 \mathrm{~kb} B g l \mathrm{II}-S s p \mathrm{I}$ fragment (Fig. 2a). The base composition of this region was $63 \mathrm{~mol} \% \mathrm{G}+\mathrm{C}$, which is practically identical to other mycobacterial genetic elements. A 1119 bp ORF starting with an ATG initiation codon at position 697 and ending in a stop codon at position 1815 was identified. The deduced protein sequence of 372 amino acid residues was aligned with other integrases (Fig. 2b). Although integrases have an overall low level of amino acid sequence similarity, their C-terminal regions can be aligned in two domains associated with the recognition of specific DNA sequences. The alignment revealed the presence of an arginine residue in the middle of the first domain, as well as histidine, arginine and tyrosine residues in the second domain, a characteristic shared by all members of the integrase family (Abremski \& Hoess, 1992; Argos et al., 1986). This observation shows that this ORF encodes the integrase of bacteriophage Ms6. A threonine residue in the first domain is also present in all the integrase sequences shown in Fig. 2(b), but is absent
Table 3. Percentage amino acid identity between different mycobacterial integrative systems

Data were obtained using the PALIGN program (structure-genetic matrix, using default settings), included in the PCGene (IntelliGenetics) software package. The GenBank accession numbers of the sequences analysed are: AF030986 (Ms6); X70352 (D29); M65194 (L5); X63702 (FRAT1); X14899 (pSAM2). The full-length amino acid sequences of the Int proteins were used in these alignments.

\begin{tabular}{|lccccc|}
\hline & Ms6 & D29 & L5 & FRAT1 & pSAM2 \\
\hline Ms6 & - & $14 \cdot 11$ & $13 \cdot 95$ & $13 \cdot 21$ & $17 \cdot 20$ \\
D29 & $14 \cdot 11$ & - & $83 \cdot 18$ & $99 \cdot 10$ & $20 \cdot 42$ \\
L5 & $13 \cdot 95$ & $83 \cdot 18$ & - & $82 \cdot 88$ & $18 \cdot 60$ \\
FRAT1 & $13 \cdot 21$ & $99 \cdot 10$ & $82 \cdot 88$ & - & $20 \cdot 72$ \\
pSAM2 & $17 \cdot 20$ & $20 \cdot 42$ & $18 \cdot 60$ & $20 \cdot 72$ & - \\
\hline
\end{tabular}

from some $\lambda$ Int-related proteins. Table 3 shows the amino acid identity between Ms6 and other mycobacterial Int-related proteins. The Int proteins of mycobacteriophages L5, D29 and FRAT1 are highly related, with identity reaching $99.1 \%$ between FRAT1 and D29. In contrast, the Ms6 integrase amino acid sequence is only poorly related to those of other mycobacteriophage Int proteins.

The attP-int region of Ms6 is delimited by two inverted repeat sequences. At the $3^{\prime}$ terminus of the int gene lies 


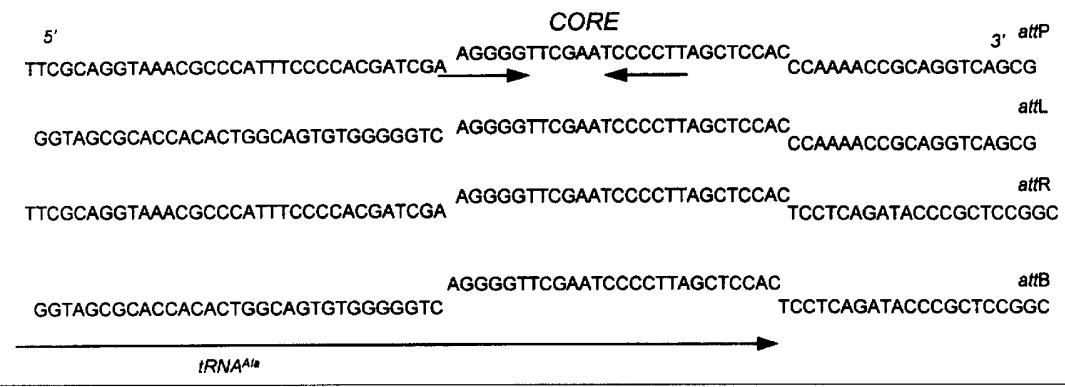

Fig. 3. Comparison of the DNA sequences of the attachment sites. The $26 \mathrm{bp}$ common core sequence is indicated. The position of the tRNA ${ }^{\text {Ala }}$ gene is represented by an arrow below the attB sequence.

a structure resembling a rho-independent transcriptional terminator that can form a hairpin secondary structure, followed by a T-rich sequence. A second inverted repeat is located at position 480 (GenBank accession number AF030986). This repeat can form a $10 \mathrm{bp}$ stem-loop, but no $\mathrm{T}$-rich sequence is present close to it, indicating that it is not part of a rho-independent terminator.

\section{Identification of the phage and bacterial attachment sites}

The common core site where the recombination between the phage DNA and the bacterial genome occurs was determined from the alignment of four DNA fragments: the right and left host-phage DNA junctions (attR and att $L$ ) between the integrative vector pAV8800 and the bacterial genome; the bacteriophage attP-int region; and the attachment site in the bacterial genome, att $B$ (Fig. 3). To identify the host-phage DNA junctions, a $\lambda$ EMBL4 library was constructed from the genome of an M. smegmatis/pAV8800 transformant (Table 1). A recombinant phage containing the complete pAV8800 sequence, inserted into an EcoRI bacterial restriction fragment, was analysed by Southern hybridization using the attP sequence as a probe. Two SalI restriction fragments $(0.9 \mathrm{~kb}$ and $1.2 \mathrm{~kb})$ containing the putative att $R$ and att $L$ sites were identified and sequenced. The region that contains the attachment site in the bacterial genome was directly amplified by PCR from $M$. smegmatis using the specific oligonucleotides P1 and M1, designed from the right and left junction sequences (see Methods). Alignment of these sequences revealed a $26 \mathrm{bp}$ common core site where the site-specific recombination between the phage DNA and the bacterial genome occurs (Fig. 3).

\section{The chromosomal attB site is located in a tRNA Ala $^{\text {A }}$ gene}

In the $M$. smegmatis genome, the common core region lies at the $3^{\prime}$ end of a sequence that shows $83.8 \%$ identity with the tRNA ${ }^{\mathrm{Ala}}$ of Micrococcus luteus and $76 \%$ with the tRNA ${ }^{\mathrm{Ala}}$ of Escherichia coli. Moreover, this target sequence possesses a characteristic base pair (G3-U70) in the amino acid acceptor stem of the tRNA structure found in all tRNA ${ }^{\mathrm{Ala}}$ species studied to date (Fig. 4) (Hou \& Schimmel, 1989). These observations indicate that Ms6 DNA is inserted at the $3^{\prime}$ end of the $M$. smegmatis $\mathrm{tRNA}{ }^{\mathrm{Ala}}$ gene.

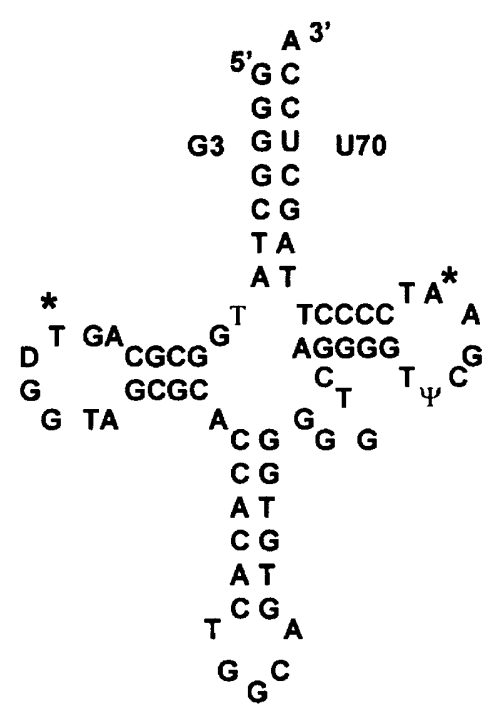

Fig. 4. Alanine tRNA encoded by the $M$. smegmatis att $B$ region. The folded structure of the alanine tRNA is shown. Asterisks indicate the altered bases in the tRNA ${ }^{\text {Ala }}$ of $M$. tuberculosis.

The common core sequence is also found in the cosmid cSCY22D7 of the gene library of M. tuberculosis H37Rv (supplied by Dr Stewart Cole, Institut Pasteur, Paris, France), sequenced by the Sanger Center (Cambridge, UK). Sequence analysis of the homologous segment in the $M$. tuberculosis genome indicates that both tRNA genes are present in a similar organization. However, there are two altered bases that lie within the D loop (a

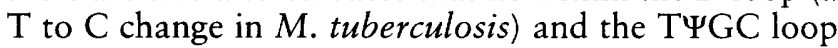
( $G$ instead of $A$ ), as shown in Fig. 4. Nevertheless, this $G$ to A change within the core region does not appear to have a significant effect on the efficiency of integration, as determined by transformation frequencies (Table 2).

\section{Construction of an integrative vector}

To demonstrate that attP and the int gene are sufficient to direct site-specific integration into the mycobacterial chromosome, a fragment of $1818 \mathrm{bp}$ containing the attP-int region was produced by PCR using primers $\mathrm{C} 2$ and PRPAV10 (Table 1) and cloned into the plasmid vector pCR3 (Invitrogen) (Fig. 2a). The recombinant plasmid pAV1 can replicate extrachromosomally in $E$. coli but not in mycobacterial cells because it does not contain a mycobacterial origin of replication. We 


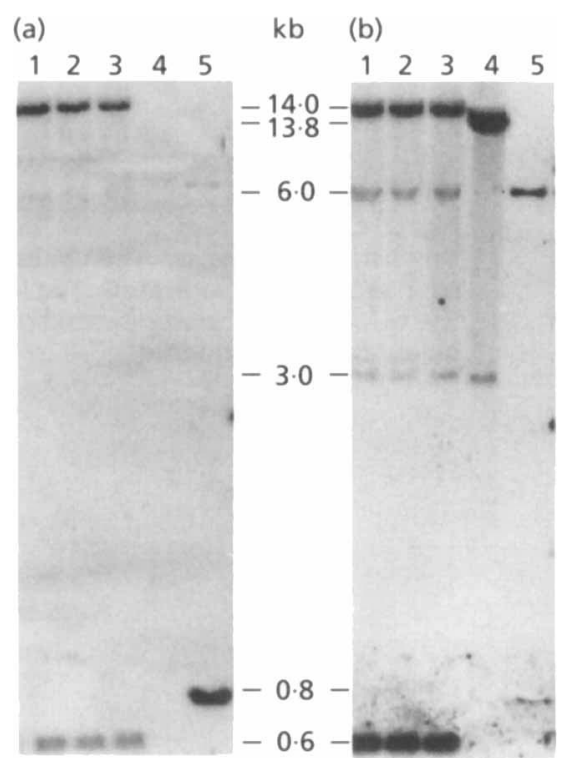

Fig. 5. Southern-hybridization analysis of $M$. smegmatis pAV1 transformants. Three independently isolated pAV1 transformants (lanes 1-3), chromosomal DNA from $M$. smegmatis (lane 4) and pAV1 (lane 5) were digested with $B a m H I$ and probed with the $0.8 \mathrm{~kb}$ Sall attP fragment (a) or with the $M$. smegmatis attB region (b).

searched for in vivo integration of pAV1 into the $M$. smegmatis, M. vaccae, M. bovis BCG and $M$. tuberculosis $\mathrm{H} 37 \mathrm{R}$ a genomes using electroporation and selection of kanamycin-resistant transformants. The number of transformants per microgram of DNA was $1.0 \times 10^{5}$ and $3.0 \times 10^{3}$ in M. smegmatis and M. bovis BCG/M. tuberculosis, respectively (Table 2). These transformation efficiencies are similar to those obtained with pRR3 (Ranes et al., 1990), a shuttle plasmid that replicates extrachromosomally in Mycobacterium spp. and E. coli. Disruption of the ORF present in the Ms6 integrative region destroys the ability to transform mycobacteria. Deletions and insertions performed on the 3 ' end of the int gene lead to non-integrative activity (data not shown).

Southern hybridization analysis confirmed that the Ms6derived integrative plasmid (pAV1) was inserted into the same site $(a t t B)$ in all transformants examined (Fig. 5). Chromosomal DNA from three independent kanamycin-resistant transformants and from pAV1 was cut with $B a m \mathrm{HI}$ and hybridized with a radiolabelled attP fragment. This probe did not hybridize with chromosomal DNA from M. smegmatis (Fig. 5a, lane 4), while two hybridizing bands of 0.6 and $14 \mathrm{~kb}$ were seen in the chromosomal digests of all the kanamycin-resistant transformants (Fig. 5a, lanes 1-3). The $0.8 \mathrm{~kb} \mathrm{BamHI}$ restriction fragment from pAV1, containing the attP region, is intact in lane 5. In Fig. 5(b), hybridization with the attB probe (an M. smegmatis $0.5 \mathrm{~kb}$ DNA fragment obtained by PCR amplification and cloned into pCR3) revealed a $13.8 \mathrm{~kb}$ fragment in $M$. smegmatis DNA (lane
4) that is absent in all transformants. Instead, in these digests the two hybrid fragments $(0.6$ and $14 \mathrm{~kb})$ were detected (lanes 1-3). The sizes of the two hybridizing bands were consistent with the predicted integration of one copy of pAV1 into the $M$. smegmatis genome at the attachment site $($ attB) present in the $13.8 \mathrm{~kb} \mathrm{BamHI}$ fragment (Fig. 5b, lane 4). The $6 \mathrm{~kb}$ restriction band in Fig. 5(b) corresponds to common sequences present in both pCR3 and pAV1 plasmids. The $3 \mathrm{~kb}$ fragment found in all $M$. smegmatis DNA digests might correspond to another region that contains sequences with high homology with this probe.

pAV1 was also efficiently integrated, by site-specific integration, in $M$. bovis BCG (Fig. 6a and b) and $M$. tuberculosis $\mathrm{H} 37 \mathrm{Ra}$ (Fig. $6 \mathrm{c}$ ) genomes. In all $M$. bovis BCG transformants, two hybrid BamHI restriction fragments of 2.4 and $8.0 \mathrm{~kb}$ were detected using the Ms6 attP region as a probe (Fig. 6a, lanes $2-5$ ). The same pattern of hybridization was obtained in M. tuberculosis pAV1 transformants (results not shown). A schematic representation of pAV1 site-specific integration in the M. tuberculosis genome is presented in Fig. 7 .

In slow-growing mycobacteria $(M$. bovis BCG and $M$. tuberculosis), the plasmid-integration target site hybridizes with the M. smegmatis attB sequence (Fig. $6 \mathrm{c}$, lane 2). However, sequences that are linked to the tRNA $^{\text {Ala }}$ gene in $M$. tuberculosis are different from those of M. smegmatis. As a consequence, the $8.0 \mathrm{~kb}$ Bam $\mathrm{HI}$ hybrid band cannot be detected by probing with the $0.5 \mathrm{~kb}$ attB region of $M$. smegmatis. With this probe, only the $2.4 \mathrm{~kb}$ BamHI hybrid band, which includes the tRNA ${ }^{\text {Ala }}$ gene, is revealed (Fig. 6c, lanes 3-5). A $7.9 \mathrm{~kb}$ cross-hybridizing band to $M$. smegmatis att $B$, common to all $M$. bovis BCG and M. tuberculosis patterns (Fig. $6 \mathrm{~b}$ and $\mathrm{c}$ ), is distinct from the $8.0 \mathrm{~kb}$ hybrid band.

It can be concluded that the pAV1 integration site in the host genome is conserved in fast- and slow-growing mycobacteria and that it overlaps the last 25 bases of the tRNA ${ }^{\mathrm{Ala}}$ gene, remaining outside this gene by a single base, cytosine (Fig. 4).

The $M$. smegmatis transformants retained the integrative plasmid for long periods of time. All the transformants tested retained kanamycin resistance after 150 generations of growth in a nonselective medium.

It is notable that the transformation efficiency and the stability of the transformants diminish when the entire $4.8 \mathrm{~kb} \mathrm{BglII}$ fragment is used for transformation (pAV8800). This instability was most apparent in $M$. bovis BCG transformants that could not be amplified. These observations suggest that an excisionase activity is encoded in this large integrative fragment.

To demonstrate that the ORF of this integrative cassette is absolutely required for site-specific integration and encodes an integrase, a nonsense mutation within the int gene was constructed by site-directed mutagenesis. It was observed that all of the mutants thus generated completely lost the ability to integrate (data not shown). 
(a)

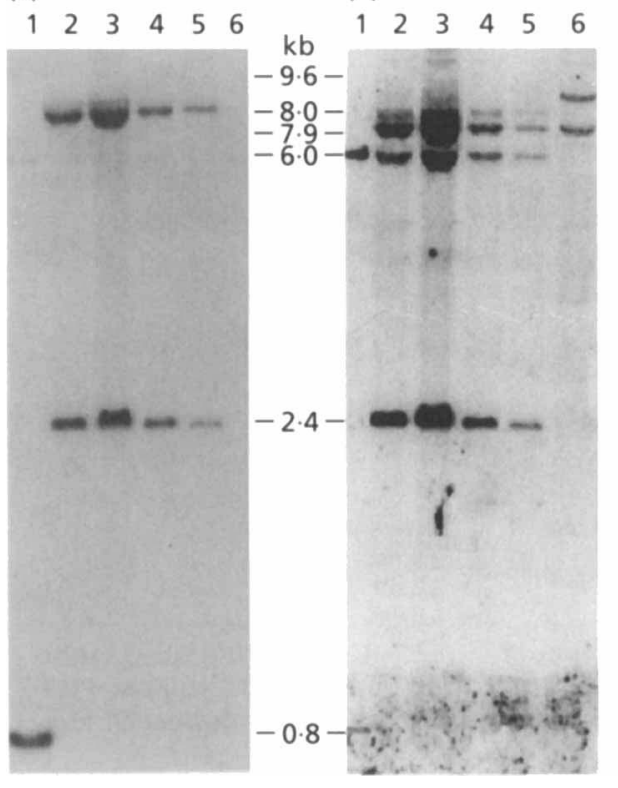

(c) $\mathrm{kb}$

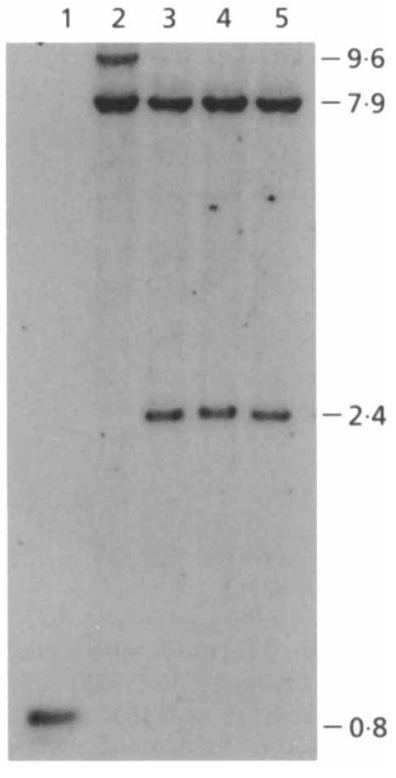

Fig. 6. Southern hybridization of BamHIdigested chromosomal DNAs of $M$. bovis BCG and $M$. tuberculosis pAV1 transformants. pAV1 (lane 1), four independent $M$. bovis BCG transformants (lanes 2-5) and $M$. bovis BCG genomic DNA (lane 6) were probed with the $0.8 \mathrm{~kb}$ Sall attP fragment (a) or with $M$. smegmatis attB DNA (b). Three $M$. tuberculosis pAV1 transformants (lanes 3-5) and $M$. tuberculosis H37Ra genomic DNA (lane 2) were also probed with $M$. smegmatis attB DNA (c).

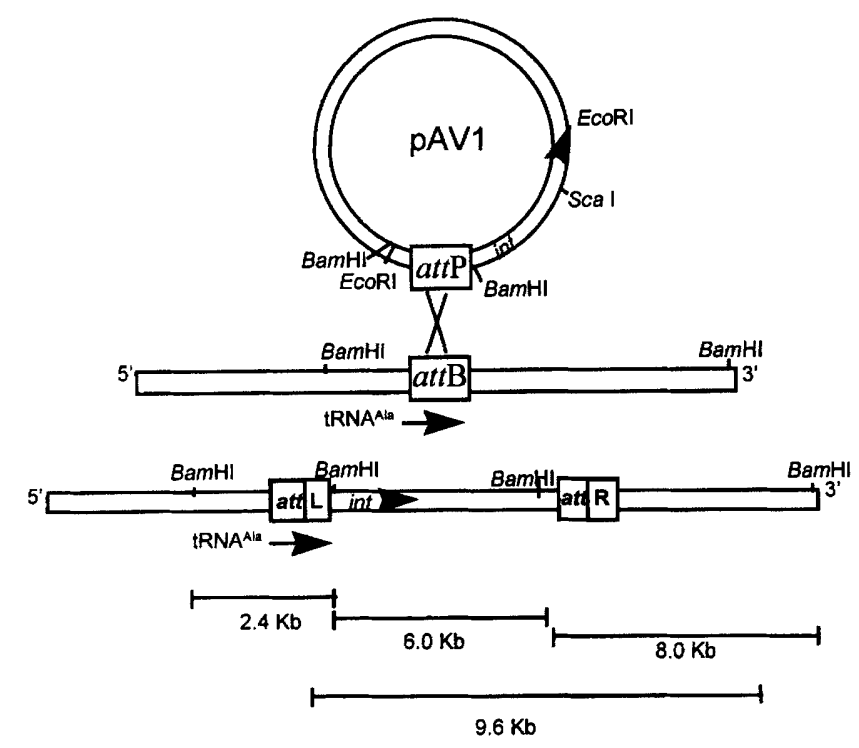

Fig. 7. Schematic representation of the pAV1 site-specific integration into the tRNA ${ }^{\mathrm{Ala}}$ gene of the $M$. tuberculosis genome. The 2.4 and $8.0 \mathrm{~kb} \mathrm{BamHl}$ fragments are the phage-host DNA junction restriction fragments.

\section{Double recombination by Ms6- and D29-derived site- specific integration vectors}

Since Ms6 and L5 prophages integrate at different specific loci in the mycobacterial genome, it is conceivable that complex recombinants can be made using integration-proficient vectors derived from both bacteriophages.

The attP-int region of mycobacteriophage D29, a member of the L.5 bacteriophage family (Table 3), was cloned into the pBK-CMV (Stratagene) plasmid vector, which contains the kanamycin-resistance gene $a p h$; the resulting plasmid was designated pRM16. The Ms6 integration region was introduced in a pUC18-derivative plasmid containing the $\Omega$ gene, which confers resistance to streptomycin (pAV $\Omega$ ). pRM16 and pAV $\Omega$ were both introduced into $M$. smegmatis by electroporation and double-recombinants were selected on plates with kanamycin and streptomycin. To confirm that, in the doublerecombinants, the two plasmids were integrated at two distinct loci in the same bacterial genome, DNA from three kanamycin-resistant, three streptomycin-resistant and three double kanamycin- and streptomycin-resistant bacterial clones was isolated, digested with Sall, and a comparative Southern hybridization analysis was performed using two probes, attB-Ms6 and attP-D29 (Fig. 8 ). The $M$. smegmatis att $B-M s 6$ region was located on a $1.0 \mathrm{~kb} \mathrm{Sall}$ fragment (Fig. 8a, lane 2). This fragment is not present in any of the streptomycin-resistant clones (lanes 3-5), which contain two new SalI fragments of 6.2 and $5.6 \mathrm{~kb}$, indicating that $\mathrm{pAV} \Omega$ was integrated into the bacterial genome at the attB-Ms6 region.

Linear pRM16 (which contains the $6.4 \mathrm{~kb}$ Sall fragment of Fig. 8c, lane 12) was disrupted to give two bands of 2.5 and $6.2 \mathrm{~kb}$ in all kanamycin-resistant transformants (Fig. 8, lanes 9-11). It is notable that in $M$. smegmatis and in pAV $\Omega$ transformants (Fig. 8, lanes 2-5), a $2.0 \mathrm{~kb}$ Sall fragment is detected. This band does not appear in pRM16 transformants, suggesting that it contains the attB-D29 region. These results show that pRM16 and $\mathrm{pAV} \Omega$ are integrated at two different genomic targets. The two types of integration patterns described above were found in each of the three independent doublerecombinant clones (Fig. 8b, lanes 6-8), demonstrating that integrated $\mathrm{pRM} 16$ and $\mathrm{pAV} \Omega$ coexist in the same genomic DNA. 
(a)

$\begin{array}{lllllllllllllll}1 & 2 & 3 & 4 & 5 & 6 & 7 & 8 & 9 & 10 & 11 & 12 & 13\end{array}$

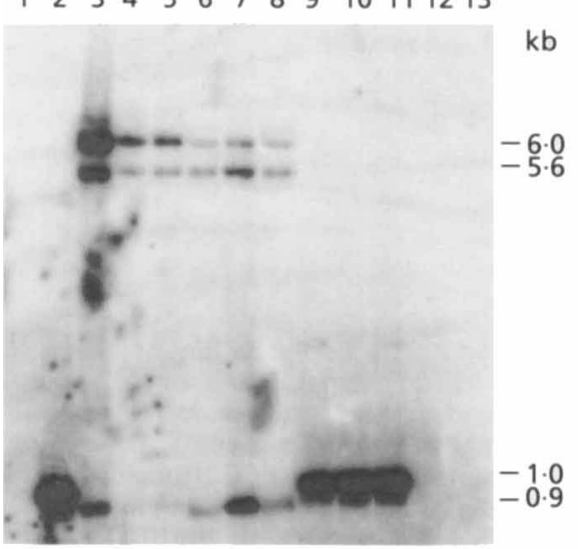

(b)

$\begin{array}{llllllllllllll}1 & 2 & 3 & 4 & 5 & 6 & 7 & 8 & 9 & 10 & 1112 & 13\end{array}$ (c)

$\begin{array}{lllllllllllllll}1 & 2 & 3 & 4 & 5 & 6 & 7 & 8 & 9 & 10 & 11 & 12 & 13\end{array}$
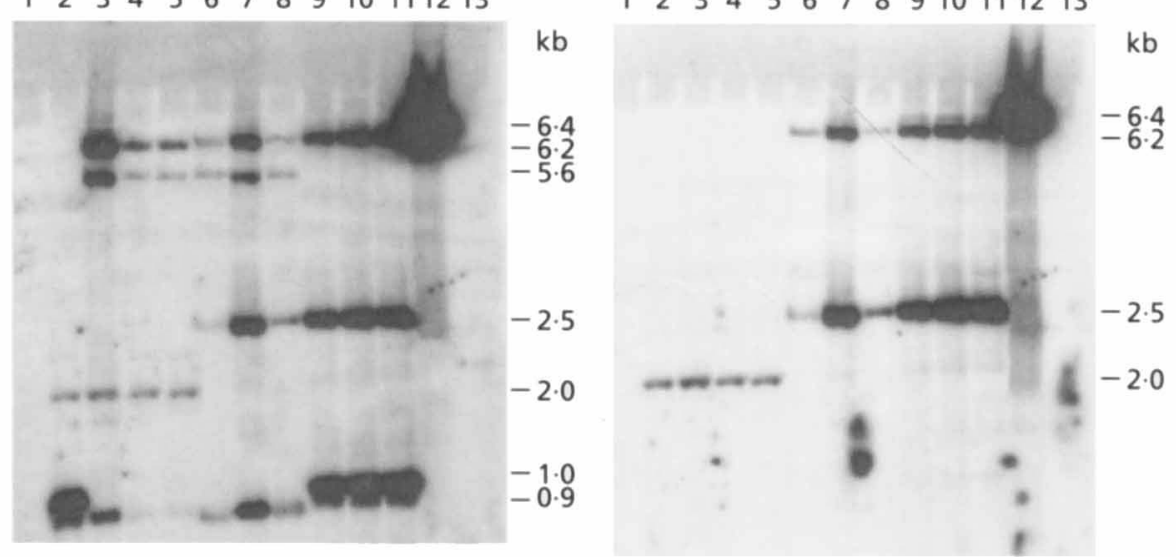

Fig. 8. Southern hybridization of genomic DNA from $M$. smegmatis transformants digested with Sall and probed with: (a) $0.5 \mathrm{~kb}$ attB-Ms6 fragment; (b) $0.5 \mathrm{~kb}$ attB-Ms6 fragment and $0.5 \mathrm{~kb}$ Kpnl-Pvul attP-D29 fragment; (c) $0.5 \mathrm{~kb}$ Kpnl-Pvul attP-D29 fragment. Lanes: 1 and 13, DNA size standards; 2, untransformed $M$. smegmatis; 3-5, pAV $\Omega$ transformants; 6-8, pAV $\Omega$ and pRM16 double-transformants; 9-11, pRM16 transformants; 12, linear pRM16.

\section{DISCUSSION}

In this study we have characterized the genetic elements involved in the site-specific integration event between bacteriophage Ms6 DNA and the mycobacterial genome. Although the genetic organization of the Ms6 integration region is similar to other bacteriophages, we have demonstrated that Ms6 does not belong to the L5 mycobacteriophage family.

The bacteriophage attachment site has a high $\mathrm{A}+\mathrm{T}$ content and is rich in direct and inverted repeats. These structures are also observed in attP sites of other temperate bacteriophages and may be the target sites for phage- and bacterial-encoded proteins such as integrase, excisionase (Weisberg \& Landy, 1983) or the equivalent of $E$. coli integration host factor (Craig \& Nash, 1984) and the FIS protein (Thompson et al., 1987). Amino acid sequence alignments showed that Ms6 Int is weakly related with the mycobacteriophage L5 (Lee et al., 1991), D29 (Peña et al., 1997) and FRAT1 (Haeseleer et al., 1992) Int proteins. The common core region where recombination occurs between Ms6 DNA and the mycobacterial genome is $26 \mathrm{bp}$. This sequence overlaps the $3^{\prime}$ end of the tRNA ${ }^{\mathrm{Ala}}$ gene and seems to be conserved in fast- and slow-growing mycobacteria. Furthermore, the core sequence does not show any homology to the common core sequence of bacteriophage $\mathrm{L} 5$, which is longer, with 43 nucleotide residues.

We demonstrated that Ms6 integrase directs the insertion at the $3^{\prime}$ end of the tRNA ${ }^{\text {Ala }}$ gene in both fastand slow-growing mycobacteria. tRNA genes are also used as insertion targets by other actinomycete genetic elements, including integrative plasmids (Omer \& Cohen, 1986; Madon et al., 1987; Mazodier et al., 1990) and temperate bacteriophages (Lee et al., 1991). The majority of actinomycete tRNA genes associated with the attB site do not contain the $3^{\prime}$ terminal CCA sequence located at position 74-76 in the structure proposed by Sprinzl et al. (1989). These tRNAs belong to class II-type genes which require a post-transcriptional modification by a nucleotidyltransferase to acquire a CCA $3^{\prime}$ end. This is also true for tRNA ${ }^{\text {Gly }}$ and tRNA ${ }^{\mathrm{Ala}}$ genes that contain the attB sites for the temperate mycobacteriophages L5 and Ms6, respectively.

In many genetic elements that mediate integration into tRNA genes, the common core sequence extends from the anticodon loop to the $3^{\prime}$ end (Reiter et al., 1989). For example, in bacteriophages HP1, P22 and L5, the points of strand exchange are separated by $7 \mathrm{bp}$ and these regions overlap domains corresponding to the anticodon loops of the tRNA ${ }^{\mathrm{Leu}}$, tRNA ${ }^{\mathrm{Thr}}$ and $\mathrm{tRNA}^{\text {Gly }}$ genes, respectively (Hauser \& Socca, 1992; Peña et al., 1996; Smith-Mungo et al., 1994). In a few examples, such as phage P4 (Pierson \& Kahn, 1987) and $\phi \mathrm{R} 73$ (Sun et al., 1991), the common core sequence is shorter, extending from the TYCG loop to the $3^{\prime}$ end. In the Ms6 attP site we found that two short inverted sequences are separated by 7 bp at the $5^{\prime}$ end of the common core sequence. This structure overlaps the TYCG loop of the tRNA ${ }^{\text {Ala }}$ gene, suggesting that the points of strand exchange lie on this stem-loop.

pAV1, an Ms6-derived integrative-proficient vector, mediates the insertion of foreign DNA into the tRNA ${ }^{\text {Ala }}$ gene of M. smegmatis, M. vaccae, M. bovis BCG and $M$. tuberculosis. The alignment of $\mathrm{tRNA}^{\mathrm{Ala}}$ genes of $M$. smegmatis and $M$. tuberculosis showed that this sequence is highly conserved and we believe that this integrative vector could also be used in other mycobacterial species.

We found a high stability in all transformants generated with this method. This feature is very useful for the 
construction of multivalent vaccines based on $M$. bovis BCG (Stover et al., 1991). The use of M. bovis BCG as an antigen-delivery system requires stable expression of the foreign DNA during the propagation in the organism.

Site-specific integration vectors are also suited for the isolation of mycobacterial virulence determinants, through the stable insertion of large DNA fragments from virulent mycobacteria into avirulent strains and the search for pathogenic recombinants in animal models (Pascopella et al., 1994). In this study we have demonstrated that complex recombinants can be made using integration-proficient vectors derived from Ms6 and D29 bacteriophages. This strategy may make the search for virulence determinants easier since two separate regions of the $M$. tuberculosis genome can be inserted into two different target sites on the bacterial chromosome.

\section{ACKNOWLEDGEMENTS}

A. Freitas-Vieira and E. Anes made equal contributions to this work. We are very grateful to Brigitte Gicquel for the enthusiastic support and helpful discussions. A. Freitas-Vieira is the recipient of a fellowship from the Associação para o Desenvolvimento do Ensino e Investigação da Microbiologia. This study was supported by contract BIO2 CT-920502 from the European Community.

\section{REFERENCES}

Abremski, K. E. \& Hoess, R. H. (1992). Evidence for a second conserved arginine residue in the integrase family of recombination proteins. Protein Eng 5, 87-91.

Anes, E., Portugal, I. \& Moniz-Pereira, J. (1992). Insertion into the Mycobacterium smegmatis genome of the $a p h$ gene through lysogenization with the temperate mycobacteriophage Ms6. FEMS Microbiol Lett 95, 21-26.

Argos, P., Landy, A., Abremski, K. \& 9 other authors (1986). The integrase family of site-specific recombinases: regional similarities and global diversity. EMBO J 5, 433-440.

Boccard, F., Smokvina, T., Pernodet, J.-L., Friedmann, A. \& Guérineau, M. (1989). The integrated conjugative plasmid pSAM2 of Streptomyces ambofaciens is related to temperate bacteriophages. EMBO J 8, 973-980.

Brasch, M. A., Pettis, G. S., Lee, S. C. \& Cohen, S. N. (1993). Localization and nucleotide sequences of genes mediating sitespecific recombination of the SLP1 element in Streptomyces lividans. J Bacteriol 175, 3067-3074.

Brown, D. P., Idler, K. B. \& Katz, L. (1990). Characterization of the genetic elements required for site-specific integration of plasmid pSE211 in Saccharopolyspora erythraea. J Bacteriol 172, 1877-1888.

Brown, D. P., Idler, K. B., Backer, D. M., Donadio, S. \& Katz, L. (1994). Characterization of the genes and attachment sites for site-specific integration of plasmid pSE101 in Saccharopolyspora erythraea and Streptomyces lividans. Mol Gen Genet 242, 185-193.

Campbell, A. M. (1962). Episomes. Adv Genet 11, 101-145.

Campbell, A. M. (1992). Chromosomal insertion sites for phages and plasmids. J Bacteriol 174, 7495-7499.

Canard, B. \& Cole, S. T. (1990). Lysogenic phages of Clostridium perfringens: mapping of the chromosomal attachment sites. FEMS Microbiol Lett 66, 323-326.

Christiansen, B., Johnsen, M. G., Stendby, E., Vogensen, F. K. \& Hammer, K. (1994). Characterization of the lactococcal temperate phage TP901-1 and its site-specific integration. J Bacteriol 176, 1069-1076.

Christiansen, B., Bronsdsted, L., Vogensen, F. K. \& Hammer, K. (1996). A resolvase-like protein is required for the site-specific integration of the temperate lactococcal bacteriophage TP901-1. $J$ Bacteriol 178, 5164-5173.

Craig, N. L. \& Nash, H. A. (1984). E. coli integration host factor binds to specific sites in DNA. Cell 39, 707-716.

Deininger, P. L. (1983). Random subcloning of sonicated DNA: application to shotgun DNA sequence analysis. Anal Biochem 129, 216-223.

Dussurget, O., Rodriguez, M. \& Smith, I. (1996). An ideR mutant of Mycobacterium smegmatis has derepressed siderophore production and an altered oxidative-stress response. Mol Microbiol 22, 535-544.

Haeseleer, F., Pollet, J.-F., Bollen, A. \& Jacobs, P. (1992). Molecular cloning and sequencing of the attachment site and integrase gene of the temperate mycobacteriophage FRAT1. Nucleic Acids Res 20, 1420 .

Hauser, M. A. \& Socca, J. J. (1992). Site-specific integration of the Haemophilus influenzae bacteriophage HP1: location of the boundaries of the phage attachment site. J Bacteriol 174, 6674-6677.

Hou, Y. M. \& Schimmel, P. (1989). Evidence that a major determinant for identity of a transfer RNA is conserved in evolution. Biochemistry 28, 6800-6804.

Lee, C. Y. \& landolo, J. J. (1986). Integration of staphylococcal phage L54a occurs by site-specific recombination: structural analysis of the attachment sites. Proc Natl Acad Sci USA 83, 5474-5478.

Lee, C. Y. \& landolo, J. J. (1988). Structural analysis of staphylococcal bacteriophage $\phi 11$ attachment sites. J Bacteriol 170, 2409-2411.

Lee, M. H., Pascopella, L., Jacobs, W. R., Jr \& Hatfull, G. F. (1991). Site-specific integration of mycobacteriophage L5: integrationproficient vectors for Mycobacterium smegmatis, Mycobacterium tuberculosis and bacille Calmette-Guérin. Proc Natl Acad Sci USA 88, 3111-3115.

Leong, J. M., Nunes-Duby, S. E., Oser, A. B., Lesser, C. F., Youderian, P., Susskind, M. M. \& Landy, A. (1986). Structural and regulatory divergence among site-specific recombination genes of lambdoid phages. J Mol Biol 189, 603-616.

Lillehaug, D. \& Birkeland, N. K. (1993). Characterization of genetic elements required for site-specific integration of the temperate lactococcal bacteriophage $\phi \mathrm{LC} 3$ and construction of integrationnegative $\phi \mathrm{LC} 3$ mutants. J Bacteriol 175, 1745-1755.

Madon, J., Moretti, P. \& Hutter, R. (1987). Site-specific integration and excision of pMEA100 in Nocardia mediterranei. Mol Gen Genet 209, 257-264.

Matsuura, M., Noguchi, T., Yamaguchi, D., Aida, T., Asayama, M., Takahashi, H. \& Shirai, M. (1996). The sre gene (ORF469) encodes a site-specific recombinase responsible for integration of the R4 phage genome. J Bacteriol 178, 3374-3376.

Mazodier, P., Thompson, C. \& Boccard, F. (1990). The chromosomal integration site of the Streptomyces element pSAM2 overlaps a putative tRNA gene conserved among actinomycetes. Mol Gen Genet 222, 431-434.

Omer, C. A. \& Cohen, S. N. (1986). Structural analysis of plasmid 
and chromosomal loci involved in site-specific excision and integration of the SLP1 element of Streptomyces coelicolor. J Bacteriol 166, 996-1006.

Pascopella, L., Collins, F. M., Martin, J. M., Lee, M. H., Hatfull, G. F., Stover, C. K., Bloom, B. R. \& Jacobs, W. R., Jr (1994). Use of in vivo complementation in Mycobacterium tuberculosis to identify a genomic fragment associated with virulence. Infect Immun 62, 1313-1319.

Peña, C. E. A., Stoner, J. E. \& Hatfull, G. F. (1996). Positions of strand exchange in mycobacteriophage L5 integration and characterization of the attB site. J Bacteriol 178, 5533-5536.

Peña, C. E. A., Lee, M. H., Pedulla, M. L. \& Hatfull, G. F. (1997). Characterization of the mycobacteriophage L5 attachment site, attP. J Mol Biol 266, 76-92.

Pierson, L. S. \& Kahn, M. L. (1987). Integration of satellite bacteriophage P4 in Escherichia coli: DNA sequences of phage and host regions involved in site-specific recombination. $J \mathrm{Mol}$ Biol 196, 487-496.

Portugal, I., Anes, E. \& Moniz-Pereira, J. (1989). Temperate mycobacteriophage from Mycobacterium smegmatis. Acta Leprol 7, S243.

Ranes, M. G., Rauzier, J., Lagranderie, M., Gheorghiu, M. \& Gicquel, B. (1990). Functional analysis of pAL5000, a plasmid from Mycobacterium fortuitum: construction of a 'mini' Mycobacterium-Escherichia coli shuttle vector. J Bacteriol 172, 2793-2797.

Rausch, H. \& Lehmann, M. (1991). Structural analysis of the actinophage $\phi \mathrm{C} 31$ attachment site. Nucleic Acids Res 19, 5187-5189.

Reiter, W. D., Palm, P. \& Yeats, S. (1989). Transfer RNA genes frequently serve as integration sites for prokaryotic genetic elements. Nucleic Acids Res 17, 1907-1914.

Sambrook, J., Fritsch, E. F. \& Maniatis, T. (1989). Molecular Cloning: a Laboratory Manual, 2nd edn. Cold Spring Harbor, NY: Cold Spring Harbor Laboratory.
Sanger, F., Nicklen, S. \& Coulson, A. R. (1977). DNA sequencing with chain-terminating inhibitors. Proc Natl Acad Sci USA 74, 5463-5467.

Smith-Mungo, L., Chan, I. T. \& Landy, A. (1994). Structure of the P22 att site. Conservation and divergence in the lambda motif of recombinogenic complexes. J Biol Chem 269, 20798-20805.

Snapper, S. B., Melton, R. E., Mustafa, S., Kieser, T. \& Jacobs, W. R., Jr (1990). Isolation and characterization of efficient plasmid transformation mutants of Mycobacterium smegmatis. Mol Microbiol 4, 1911-1919.

Sprinzl, M., Hartmann, T., Weber, J., Blank, J. \& Zeidler, R. (1989). Compilation of $\mathrm{tRNA}$ sequences and sequences of $\mathrm{tRNA}$ genes. Nucleic Acids Res 17, 1-172.

Stover, C. K., de la Cruz, V. F., Fuerst, T. R. \& 14 other authors (1991). New use of BCG for recombinant vaccines. Nature 351, 456-460.

Sun, J., Inouye, M. \& Inouye, S. (1991). Association of a retroelement with a P4-like cryptic prophage (retronphage $\phi \mathrm{R} 73$ ) integrated into the selenocystyl tRNA gene of Escherichia coli. J Bacteriol 173, 4171-4181.

Thompson, J. F., Moitoso de Vargas, L., Koch, R., Kahmann, R. \& Landy, A. (1987). Cellular factors couple recombination with growth phase: characterization of a new component in the lambda site-specific recombination pathway. Cell 50, 901-908.

Weisberg, R. A. \& Landy, A. (1983). Site-specific recombination in phage lambda. In Lambda, vol. 2, pp. 211-250. Edited by W. Hendrix, J. W. Roberts, F. W. Stahl \& R. A. Weisberg. Cold Spring Harbor, NY: Cold Spring Harbor Laboratory.

Yanisch-Perron, C., Vieira, J. \& Messing, J. (1985). Improved M13 phage cloning vectors and host strains: nucleotide sequences of the M13mp18 and pUC19 vectors. Gene 33, 103-119.

Received 30 March 1998; revised 3 July 1998; accepted 11 August 1998. 